Egyptian Journal of Aquatic Biology \& Fisheries

Zoology Department, Faculty of Science,

Ain Shams University, Cairo, Egypt.

ISSN $1110-6131$

Vol. 25(2): 875 - 896 (2021)

www.ejabf.journals.ekb.eg

\title{
Evaluation of Heavy Metals Pollution in Seawater, Suspended Particulate Matter and Sediment from Abu-Qir Bay, Alexandria, Egypt
}

\section{Laila Mohamed, Dalia Salem*, Ahmed Radwan}

National Institute of Oceanography and Fisheries, NIOF, Egypt

*Corresponding Author: prof_dalia@yahoo.com

\section{ARTICLE INFO}

Article History:

Received: April 16, 2021

Accepted: April 27, 2021

Online: April 30, 2021

Keywords:

Abu-Qir Bay;

Heavy metals;

Distribution coefficient;

Water Quality Index

\section{ABSTRACT}

The level of heavy metals ( $\mathrm{Mn}, \mathrm{Fe}, \mathrm{Co}, \mathrm{Ni}, \mathrm{Cu}, \mathrm{Zn}, \mathrm{Pb}$, and $\mathrm{Cd}$ ) in seawater, suspended particulate matter (SPM) and sediment along Abu-Qir Bay coast, Alexandria, Egypt, were evaluated by selecting nine stations as hot spots during winter 2020. Resuls showed that, the average concentrations of the investigated heavy metals followed the following order: $\mathrm{Fe}>\mathrm{Zn}>\mathrm{Mn}>\mathrm{Ni}>$ $\mathrm{Pb}>\mathrm{Co}>\mathrm{Cu}>\mathrm{Cd}$ in seawater, $\mathrm{Fe}>\mathrm{Zn}>\mathrm{Mn}>\mathrm{Pb}>\mathrm{Cu}>\mathrm{Ni}>\mathrm{Co}>\mathrm{Cd}$ in $\mathrm{SPM}$, and $\mathrm{Fe}>\mathrm{Mn}>\mathrm{Zn}>\mathrm{Ni}>\mathrm{Co}>\mathrm{Cu}>\mathrm{Pb}>\mathrm{Cd}$ in sediment. Moreover, the distribution coefficient $(K d)$ revealed that, $\mathrm{Fe}$ was highly stable in sediments, and the $\log (K d)$ value was 6.521 in all water bodies. In addition, geoaccumulation index $\left(I_{\text {geo }}\right)$, pollution load index (PLI), modified degree of contamination $\left(m C_{d}\right)$, potential ecological risk index $(R I)$, as well as the mean effect range median quotient $(M E R M-Q)$ were calculated. Calculations recorded that, the values of $I_{g e o}$ for Cd in surface sediments ranged between 1 and 3 indicating that, the study sites were moderate to strongly contaminated with $\mathrm{Cd}$. The $m C_{d}$ values of $\mathrm{Ni}, \mathrm{Cu}, \mathrm{Zn}, \mathrm{Pb}$, and $\mathrm{Cd}$ ranged between 1.32 and 4.24 , reflecting a low to moderate degree of contamination. The studied metals presented a moderately toxic ecological risk $(150 \leq \mathrm{RI}<300)$ except for St 5 \& St 8, that showed a considerable toxic ecological risk $(R I>300)$. Based on $M E R M-Q$ classification, all samples had medium-low toxicity; $\mathrm{Ni}, \mathrm{Cu}, \mathrm{Zn}$, and $\mathrm{Pb}$ may be originated from anthropogenic sources, whereas $\mathrm{Cd}$ emerged from natural sources with some contribution of anthropogenic source. Redundancy analysis (RDA) revealed that the TOC \% and fine sand \% of the sediment had a certain influence on the Fe enrichment. The data of the water quality index (WQI) revealed that St $\mathbf{2}$, St 3, St 4, St 5 \& St $\mathbf{6}$ were slightly polluted, and could be considered hot spots.

\section{INTRODUCTION}

The contamination of coastal and marine environments by heavy metals is a worldwide problem not only in the developing countries, but also in the developed ones as well (Boran et al., 2010). Industrial and agricultural activities, vehicle emissions, domestic waste, and shipping traffic, especially in and close to harbors, are causes of heavy metal pollution (Masindi \& Muedi, 2018). Heavy metals are toxic, long 
persistent, not easily oxidized, degraded, taken away, or converted to less harmful components through biological or chemical processes, which severely damage marine environments (Sun et al., 2020).

Coastal systems like bays receive considerable quantities of heavy metals (Cao et al., 2018), among which is Abu-Qir Bay, a shallow semi-circular basin situated $35 \mathrm{~km}$ east of Alexandria city. It extends for about $50 \mathrm{~km}$ from Abu-Qir Head-Montazah in the west to Rosetta mouth of the Nile River in the east, and northwards to about $40 \mathrm{~km}$ in the Mediterranean Sea (Fig 1). The surface area of the Bay is about $360 \mathrm{~km}^{2}$ and its water volume is $4.3 \mathrm{~km}^{3}$, while the maximum depth reaches $22 \mathrm{~m}$ (Abdel Ghani et al., 2013). It is noteworthy that the Bay receives several discharges as; freshwater from Rosetta mouth of the Nile River loaded by nutrients, industrial and domestic wastes from El-Tabia pumping station (TPS), and the outlet of Lake Edku (Boughaz El-Maddya) carrying trace metals, pesticides, humic acids, and nutrients. In addition, it receives industrial wastewaters from 22 different factories of paper, fertilizer, food processing and canning, and textile manufacturing industries. The Bay is also exposed to pollution from the activities of gas production and Abu-Qir Electrical Power Station (EPS) as well as fishing boats.

Hence, sediment should be analyzed to assess levels of contamination by heavy metals in the aquatic environment because heavy metal concentrations in water are sometimes lower than the detection limits (Salati and Moore, 2010). Therefore, sediments are considered as sensitive indicators to monitor contaminants in the aquatic systems (Pekey et al., 2004). Furthermore, high concentrations of heavy metals in sediment can indicate anthropogenic sources (Tylmann, 2011).

The main objective of the current study was to the assess the heavy metals contamination in Abu-Qir Bay sediment. That target was achieved by identifying the sources of pollution, evaluating the environmental impact of contaminated sediments, and setting an application of principal component analysis and RDA to investigate the distribution and source relationship of the heavy metals in seawater, particulate matter, and sediments. Moreover, the current study was conducted to evaluate the water quality index (WQI) of Abu-Qir Bay through measuring some physical and chemical parameters; the temperature of water, salinity, $\mathrm{pH}$, dissolved oxygen (DO), oxidizable organic matter (OOM), and total alkalinity (T. Alk.) in the surface water as well as heavy metals, (Mn, $\mathrm{Fe}, \mathrm{Co}, \mathrm{Ni}, \mathrm{Cu}, \mathrm{Zn}, \mathrm{Pb}$, and $\mathrm{Cd}$ ) in water and suspended particulate matter (SPM). This task was managed by studying nine stations (St 2 to St 10) in front of Abu-Qir city, AbuQir EPS, Boughaz El-Maddya, TPS, and the paper and fertilizer factories in Abu-Qir area. 


\section{MATERIALS AND METHODS}

\section{Sampling}

Triplicate surface sediment ( 7 samples), and seawater ( 9 samples) were collected from nine stations during winter 2020, representing the hot spots influenced by human activities; industrial and agriculture discharge along Abu-Qir Bay, Alexandria (Figure 1). The Sediment samples were collected using Van-Veen grab sampler, packed in clean polyethylene bags, and preserved at $4^{\circ} \mathrm{C}$ in an ice box. Before analysis, the samples were dried at room temperature and grinded using an agate mortar. Seawater samples were collected using PVC Niskin's bottle, packed in pre-washed plastic bottles, and stored at $4^{\circ} \mathrm{C}$ for preservation and laboratory analysis to evaluate physicochemical parameters and heavy metals.

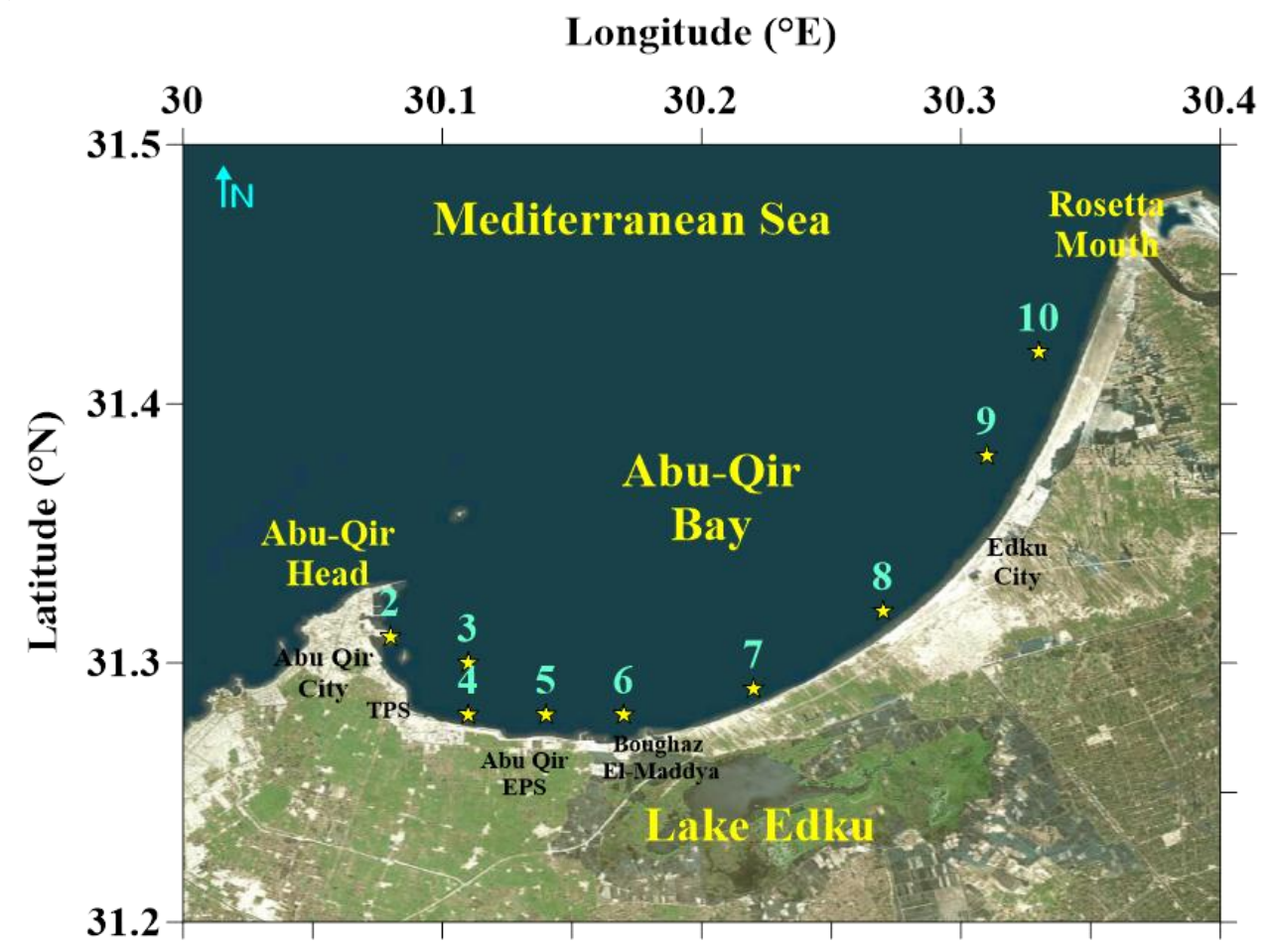

Figure 1. Abu-Qir Bay area and sampling locations.

\section{Analytical methods}

\subsection{Physicochemical parameters of seawater}

The water sample was sub-sampled and immediately the following parameters were measured in-situ i) water temperature, $\mathrm{pH}$ and salinity using calibrated CTD device, model, (YSI 6000). ii) Fixing of dissolved oxygen (DO). Then, at laboratory DO was determined by using Winkler's method (Grasshoff $\boldsymbol{e t}$ al., 1999), Oxidizable organic matter (OOM) was determined using the method depicted by FAO (1976), and total alkalinity (T. Alk.) was determined according to APHA (1995). 


\subsection{Dissolved and particulate heavy metals in seawater}

The volume of water samples (3-4 L) was filtered using $0.45 \mu \mathrm{m}$ membrane filter paper. The dissolved metal ions were determined after preconcentration using the cation exchange resin (chelex-100 in ammonia form) following the decription of Gao et al. (2002). The membrane filters with their content of suspended particulate matter (SPM) were washed several times, and then dried at $65{ }^{\circ} \mathrm{C}$ for $48 \mathrm{hrs}$ to a constant weight. Each dried membrane filter was placed in a Teflon cup, a mixture of $\mathrm{HNO}_{3}-\mathrm{HClO}_{4}-\mathrm{HF}(3: 2: 1)$ $(6 \mathrm{ml})$ was added, and the Teflon cup was then heated. After complete digestion, the sample was evaporated until dryness, then $6 \mathrm{~N} \mathrm{HNO}_{3}(1 \mathrm{ml})$ was added and the volume was completed with $0.1 \mathrm{~N} \mathrm{HCl}$ to the final volume of $25 \mathrm{ml}$ (Abdullah \& Royle, 1974). The concentrations of $\mathrm{Mn}, \mathrm{Fe}, \mathrm{Co}, \mathrm{Ni}, \mathrm{Cu}, \mathrm{Zn}, \mathrm{Pb}$, and $\mathrm{Cd}$ were determined by ICP-OES (Agilent). The results were expressed in $\mu \mathrm{g} / \mathrm{L}$ for both seawater and SPM.

\subsection{Heavy metals in Sediments}

The heavy metals in surface sediments were digested according to the method described by Oregioni and Astone (1984). Exact weight of each dried sediment sample (about $0.25-0.3 \mathrm{~g}$ ) was placed in a Teflon beaker. Concentrated $\mathrm{HNO}_{3}(3 \mathrm{ml})$ was added dropwise to the sample. The outcome was then heated at $80{ }^{\circ} \mathrm{C}$ until dryness, then a mixture of $\mathrm{HNO}_{3} / \mathrm{HClO}_{4} / \mathrm{HF}(3: 2: 1)(5 \mathrm{ml})$ was added to the sample. After complete digestion, temperature was increased gradually to $120{ }^{\circ} \mathrm{C}$ to evaporate the $\mathrm{HClO}_{4}$ residue. Afterwards the sample was cooled at room temperature, and the residue was rinsed with $0.1 \mathrm{~N} \mathrm{HCl}(5 \mathrm{ml})$. The sample was filtered and washed several times with deionized water, and the final volume was adjusted to $25 \mathrm{ml}$. The concentrations of $\mathrm{Mn}, \mathrm{Fe}, \mathrm{Co}, \mathrm{Ni}, \mathrm{Cu}$, $\mathrm{Zn}, \mathrm{Pb}$, and $\mathrm{Cd}$ were measured by ICP-OES (Agilent). The results were expressed in $\mathrm{mg} / \mathrm{kg}$ dry weight.

\subsection{Geochemical parameters of sediments}

The grain size analysis was determined by the dry sieving the method of Folk (1974), and the sediment texture was classified according to Folk (1980). The total organic carbon (TOC) was determined according to the method reported by Gaudette and Flight (1974). According to that method, the sediment sample was oxidized by $\mathrm{K}_{2} \mathrm{Cr}_{2} \mathrm{O}_{7}$ and concentrated $\mathrm{H}_{2} \mathrm{SO}_{4}$, then the excess dichromate was titrated against $(\mathrm{NH} 4)_{2} \mathrm{Fe}(\mathrm{SO} 4)_{2} \cdot 6 \mathrm{H}_{2} \mathrm{O}$ solution and diphenylamine was used as an indicator.

\subsection{Quality control and quality assurance}

The reagents used during the present study were of analytical grade (Merck), triplicate analysis for samples showed good accuracy. All glassware and plastic vessels were washed with solution of diluted $\mathrm{HNO}_{3}$ and deionized water, then they were dried. To test the precision, blanks were treated using the same reagents as samples. IAEA certified reference material, for marine sediment (SD-M-2/TM), was employed for quality control. In this study the precision of measurements for all metals was within 10 $\%$ RSD. In terms of preparing the solution, seawater certified reference materials CASS-4 
from National Research Council (NRC) in Canada, were treated in a way similar to that used for the other samples. The recovery of the selected metals ranged from 92 to $110 \%$ and the precision was within $10 \%$ RSD.

\subsection{Statistical analysis}

Principal component analysis (PCA), as a varimax rotated was conducted with IBM-SPSS program (version 22) applying Kaiser normalization.

\section{RESULTS AND DISCUSSION}

\section{Seawater physicochemical parameters}

The horizontal distributions of physicochemical parameters of Abu-Qir Bay seawater are presented in Figure (2). Abu-Qir seawater temperature ranged from 16.10 to $17.16{ }^{\circ} \mathrm{C}$, and the max value was found near Abu-Qir EPS (St 5). The recorded temperature values flowed the behavior of winter season (Radwan, 1996; Zakaria $\boldsymbol{e t}$ al., 2019). The salinity ranged from 37.24 to 38.21 , and the max value was observed at St $\mathbf{5}$. Changes in salinity may be attributed to fresh - marine water mixing. The salinity of AbuQir Bay coastal water was influenced by the discharge of wastewater from the surrounding urbanized area (Zakaria et al., 2019). The $\mathrm{pH}$ values of seawater ranged between 7.13 and 8.61, indicating that it was in the slightly alkaline side. This may be because of increasing phytoplankton and the photosynthesis processes that resulted in higher $\mathrm{pH}$ values as well as an increase in the dissolved oxygen concentrations (Das $\boldsymbol{e t}$ al., 1997). Moreover, the values of DO ranged between $8.64 \mathrm{mg} / \mathrm{L}$ at Sts $2, \mathbf{3}, 4$ \& 5 and $10.24 \mathrm{mg} / \mathrm{L}$ at Sts $9 \& \mathbf{1 0}$. Based on temporal variations, the DO in surface water recorded the highest values that could be related to the entry of oxygen from the atmosphere into the surface water and then to the algal photosynthesis (Das et al., 1997). Whereas the low values of DO may be due to the decomposition of organic matter and respiration of marine organisms as well as the biochemical reactions (Das et al., 1997). It was noticed that, the average value of OOM was 2.92, with a maximum value of 10.24 $\mathrm{mgO}_{2} / \mathrm{L}$ at St 2 and a minimum of $0.32 \mathrm{mgO}_{2} / \mathrm{L}$ at Sts $\mathbf{5}, 7 \& \mathbf{8}$. The high value of OOM at St 2 could be attributed to the impact of huge organic pollutants flow from TPS and Rosetta mouth (Alam El-Din \& Al-Hogaraty, 2001). The values of T. Alk. ranged between $3.00 \mathrm{mmol} / \mathrm{L}$ at $\mathrm{St} \mathbf{8}$ and $4.80 \mathrm{mmol} / \mathrm{L}$ at $\mathrm{St} \mathbf{6}$, with an average value of 3.29 $\mathrm{mmol} / \mathrm{L}$. The change in $\mathrm{pH}$, salinity, $\mathrm{DO}$, and alkalinity may be due to the water flow of TPS (Figure 2).

\section{Heavy metals distribution in seawater}

The fluctuations of heavy metals concentration in seawater of Abu-Qir Bay are presented in Table (1). The range and average concentrations $(\mu \mathrm{g} / \mathrm{L})$ were $1.467-12.738$ (5.716) for $\mathrm{Mn}, 7.242-22.594$ (14.502) for Fe, 0.508-3.119 (1.632) for Co, 1.808-9.398 
(5.103) for $\mathrm{Ni}, 0.458-3.738$ (1.432) for $\mathrm{Cu}, 4.600-18.333$ (12.014) for $\mathrm{Zn}, 1.625-9.325$ (4.733) for $\mathrm{Pb}$, and 0.333-2.090 (0.874) for $\mathrm{Cd}$. Though the highest concentrations of $\mathrm{Mn}$, $\mathrm{Co}, \mathrm{Cu}$ and $\mathrm{Pb}$ were detected at $\mathrm{St} \mathbf{3}$, yet the highest levels of $\mathrm{Zn}$ and $\mathrm{Cd}$ were detected at St 10 \& St 2, respectively. Remarkably, St 5 showed the highest concentrations of Fe and $\mathrm{Ni}$. On the other side, St 8 presented the lowest levels of $\mathrm{Mn}, \mathrm{Co}, \mathrm{Ni}, \mathrm{Cu}, \mathrm{Zn}, \mathrm{Pb}$ and $\mathrm{Cd}$, whilst the lowest concentration of Fe was recorded at St 4.

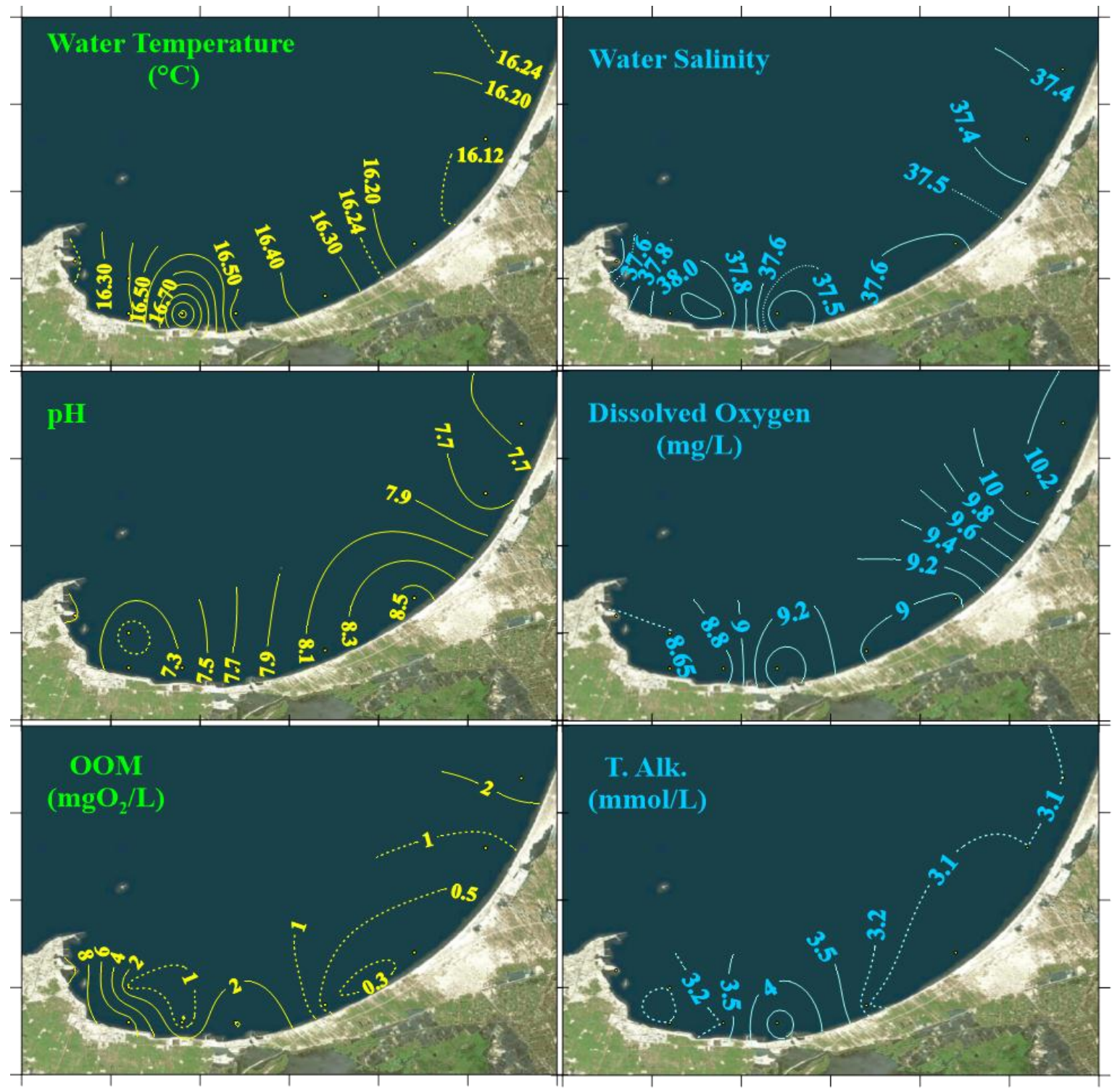

Figure 2. Horizontal distribution of some physicochemical parameters of Abu-Qir Bay seawater.

High values of $\mathrm{Ni}(8.783 \mu \mathrm{g} / \mathrm{L}), \mathrm{Pb}(7.079 \mu \mathrm{g} / \mathrm{L})$ and $\mathrm{Cd}(1.421 \mu \mathrm{g} / \mathrm{L})$ were detected at St 7, St 10 \& St 3, respectively. Besides, high concentrations of Zn (18.111 \& 16.159 $\mu \mathrm{g} / \mathrm{L})$ were measured at St 3 \& 6, respectively. Low values of $\mathrm{Mn}(1.483 \mu \mathrm{g} / \mathrm{L}), \mathrm{Cu}$ $(0.542 \mu \mathrm{g} / \mathrm{L})$ and $\mathrm{Zn}(4.658 \mu \mathrm{g} / \mathrm{L})$ were recorded at St 4. Moreover, low concentrations of Cd $(0.458$ \& $0.471 \mu \mathrm{g} / \mathrm{L})$ were measured at St 4 \& St 6, respectively. In Abu-Qir Bay seawater, Fe and $\mathrm{Zn}$ were the prevailing metals, whilst $\mathrm{Cd}$ was the least abundant (Table 
1). The average concentrations of the studied heavy metals followed the successive sequence of $\mathrm{Fe}>\mathrm{Zn}>\mathrm{Mn}>\mathrm{Ni}>\mathrm{Pb}>\mathrm{Co}>\mathrm{Cu}>\mathrm{Cd}$.

\section{Heavy metals distribution in SPM}

The fluctuations of heavy metal concentrations in SPM of Abu-Qir Bay seawater were presented in Table (1). The range and average concentrations $(\mu \mathrm{g} / \mathrm{L})$ were 1.811 12.645 (5.502) for $\mathrm{Mn}, 118.243-414.754$ (277.282) for Fe, 0.092-0.858 (0.440) for Co, 1.115-3.575 (1.733) for $\mathrm{Ni}, 0.542-4.833$ (1.886) for $\mathrm{Cu}, 3.325-26.652$ (10.377) for $\mathrm{Zn}$, 0.542-4.659 (2.182) for $\mathrm{Pb}$, and 0.008-0.292 (0.110) for $\mathrm{Cd}$. The highest concentrations of $\mathrm{Mn}, \mathrm{Cu}, \mathrm{Zn}$ and $\mathrm{Pb}$ were detected at $\mathrm{St} \mathbf{6}$, whereas the highest levels of Co and $\mathrm{Ni}$ were observed at St 4. Meanwhile, St 2 \& St 7 showed the highest values of Fe and $\mathrm{Cd}$, respectively. On the other side, St 7 presented the lowest concentrations of $\mathrm{Co}, \mathrm{Cu}, \mathrm{Zn}$ and $\mathrm{Pb}$, while the lowest values of $\mathrm{Mn}$ and $\mathrm{Fe}$ were recorded at $\mathrm{St} \mathbf{9}$. In addition, St 2 \& St 5 presented the lowest values of $\mathrm{Ni}$ and $\mathrm{Cd}$, respectively. Markedly, high values of $\mathrm{Zn}$ $(19.000 \mu \mathrm{g} / \mathrm{L})$ and $\mathrm{Pb}(4.413 \mu \mathrm{g} / \mathrm{L})$ were detected at St 10. Besides, high concentrations of Fe $(345.635,394.167 \& 338.281 \mu \mathrm{g} / \mathrm{L})$ were recorded at St 3, St 4 \& St 5, respectively. The average concentrations of the studied heavy metals in SPM followed the sequence of: $\mathrm{Fe}>\mathrm{Zn}>\mathrm{Mn}>\mathrm{Pb}>\mathrm{Cu}>\mathrm{Ni}>\mathrm{Co}>\mathrm{Cd}$.

Table 1. Heavy metals concentrations in seawater and SPM of Abu-Qir Bay.

\begin{tabular}{|c|c|c|c|c|c|c|c|c|c|c|c|c|c|c|c|c|}
\hline \multirow{3}{*}{ St No } & \multicolumn{16}{|c|}{ Heavy metals concentrations $(\mu \mathrm{g} / \mathrm{L})$} \\
\hline & \multicolumn{2}{|c|}{ Mn } & \multicolumn{2}{|r|}{$\mathbf{F e}$} & \multicolumn{2}{|c|}{ Co } & \multicolumn{2}{|c|}{$\mathbf{N i}$} & \multicolumn{2}{|c|}{$\mathbf{C u}$} & \multicolumn{2}{|c|}{$\mathbf{Z n}$} & \multicolumn{2}{|c|}{$\mathbf{P b}$} & \multicolumn{2}{|c|}{ Cd } \\
\hline & D & $\mathbf{P}$ & D & $\mathbf{P}$ & $\mathbf{D}$ & $\mathbf{P}$ & $\mathbf{D}$ & $\mathbf{P}$ & D & $\mathbf{P}$ & $\mathbf{D}$ & $\mathbf{P}$ & D & $\mathbf{P}$ & D & $\mathbf{P}$ \\
\hline 2 & 3.434 & 6.639 & 16.311 & 414.754 & 2.139 & 0.418 & 4.631 & 1.115 & 1.303 & 2.279 & 8.730 & 7.148 & 5.541 & 1.418 & 2.090 & 0.164 \\
\hline 3 & 12.738 & 4.413 & 16.960 & 345.635 & 3.119 & 0.262 & 5.802 & 1.349 & 3.738 & 2.611 & 18.111 & 12.937 & 9.325 & 3.135 & 1.421 & 0.087 \\
\hline 4 & 1.483 & 6.050 & 7.242 & 394.167 & 1.025 & 0.858 & 4.125 & 3.575 & 0.542 & 1.183 & 4.658 & 5.067 & 2.708 & 0.900 & 0.458 & 0.183 \\
\hline 5 & 5.328 & 6.359 & 22.594 & 338.281 & 2.078 & 0.227 & 9.398 & 1.773 & 1.375 & 0.703 & 13.367 & 3.773 & 5.219 & 0.586 & 0.828 & 0.008 \\
\hline 6 & 7.580 & 12.645 & 12.514 & 299.638 & 0.993 & 0.659 & 4.536 & 2.181 & 1.261 & 4.833 & 16.159 & 26.652 & 2.652 & 4.659 & 0.471 & 0.029 \\
\hline 7 & 3.792 & 2.658 & 16.925 & 220.417 & 1.533 & 0.092 & 8.783 & 1.317 & 1.083 & 0.542 & 11.558 & 3.325 & 3.975 & 0.542 & 0.667 & 0.292 \\
\hline 8 & 1.467 & 3.283 & 13.125 & 160.833 & 0.508 & 0.417 & 1.808 & 1.442 & 0.458 & 1.867 & 4.600 & 10.042 & 1.625 & 2.508 & 0.333 & 0.025 \\
\hline 9 & 9.074 & 1.811 & 10.709 & 118.243 & 1.709 & 0.554 & 3.439 & 1.162 & 1.466 & 1.230 & 12.608 & 5.446 & 4.473 & 1.480 & 0.628 & 0.095 \\
\hline 10 & 6.548 & 5.659 & 14.135 & 203.571 & 1.579 & 0.476 & 3.405 & 1.683 & 1.659 & 1.722 & 18.333 & 19.000 & 7.079 & 4.413 & 0.968 & 0.103 \\
\hline Min & 1.467 & 1.811 & 7.242 & 118.243 & 0.508 & 0.092 & 1.808 & 1.115 & 0.458 & 0.542 & 4.600 & 3.325 & 1.625 & 0.542 & 0.333 & 0.008 \\
\hline Max & 12.738 & 12.645 & 22.594 & 414.754 & 3.119 & 0.858 & 9.398 & 3.575 & 3.738 & 4.833 & 18.333 & 26.652 & 9.325 & 4.659 & 2.090 & 0.292 \\
\hline Average & 5.716 & 5.502 & 14.502 & 277.282 & 1.632 & 0.440 & 5.103 & 1.733 & 1.432 & 1.886 & 12.014 & 10.377 & 4.733 & 2.182 & 0.874 & 0.110 \\
\hline $\begin{array}{c}* \text { Marine } \\
\text { Guideline }\end{array}$ & & & & & 1.0 & & 70.0 & & 1.3 & & 15.0 & & 4.4 & & 5.5 & \\
\hline $\begin{array}{l}\text { The Criterion } \\
\text { Continuous } \\
\text { Concentration } \\
(* * \mathrm{CCC})\end{array}$ & & & & & & & 7.7 & & 2.6 & & 76.6 & & 8.1 & & 8.7 & \\
\hline $\begin{array}{l}* * * \text { Minimal } \\
\text { Risk Conc. }\end{array}$ & 20.0 & & 50.0 & & & & 2.0 & & 10.0 & & 20.0 & & 10.0 & & & \\
\hline
\end{tabular}

D: Dissolved heavy metals, P: Heavy metals in SPM, * Australian water quality guideline values suitable for the protection of $95 \%$ of all species (ANZECC/ARMCANZ, 2000), ** National Recommended Water Quality Criteria (US EPA, 2006), ***WWorld quality criteria (WQC, 1972). 


\section{Sediment characterization}

The results of sediment grain size and total organic carbon (TOC \%) of surface sediment of Abu-Qir Bay are listed in Table (2). The results of grain size showed a little variation and a uniform distribution from fine sand to silt sand. Finding the fine sediment can be due to human and terrestrial activities (El Nemr \& El-Said, 2017). As shown in table (2), sand content varied from $99.89 \%$ at St 8 \& St 9 to $23.74 \%$ at St 2. Whereas silt content varied from $68.35 \%$ at St 5 to $0.10 \%$ at St 9. TOC \% in Abu-Qir Bay sediment, recording rangee from $0.59 \%$ at St 9 to $1.95 \%$ at St 7, with an average value of $1.26 \%$. Except for St $5 \&$ St 9, the TOC \% recorded for all sediment samples was $>1$, which is slightly higher than LEL and SEL (Persaud et al., 1992).

\section{Heavy metals in sediments}

The variations of heavy metal concentrations in the surface sediment of Abu-Qir Bay are given in Table (2. The range and average concentrations $(\mathrm{mg} / \mathrm{kg})$ were 416.477 1803.088 (862.857) for Mn, $29318.380-81203.242$ (52549.293) for Fe, 29.642-68.579 (40.733) for $\mathrm{Co}, 47.341-112.765$ (71.957) for $\mathrm{Ni}, 14.288-49.594$ (30.021) for $\mathrm{Cu}, 63.975-$ 204.539 (115.805) for $\mathrm{Zn}, 17.384-46.065$ (28.186) for $\mathrm{Pb}$, and 1.208-4.599 (2.570) for $\mathrm{Cd}$. The highest concentrations of $\mathrm{Zn}, \mathrm{Pb}$, and $\mathrm{Cd}$ were detected at $\mathrm{St} \mathbf{5}$, while St 8 revealed the highest contents of Fe, $\mathrm{Co}$, and Ni. The highest levels of $\mathrm{Mn}$ and $\mathrm{Cu}$ were recorded at St $\mathbf{6} \&$ St 10, respectively. On the other side, St 7 showed the lowest values of $\mathrm{Mn}, \mathrm{Co}, \mathrm{Ni}, \mathrm{Cu}, \mathrm{Zn}$ and $\mathrm{Cd}$. The lowest concentrations of $\mathrm{Fe}$ and $\mathrm{Pb}$ were recorded at $\mathrm{St} 6$ \& St 10, respectively.

Table 2. Heavy metal concentrations, textural parameters, and TOC in sediment of Abu-Qir Bay.

\begin{tabular}{|c|c|c|c|c|c|c|c|c|c|c|c|c|}
\hline \multirow{3}{*}{$\begin{array}{c}\text { Station } \\
\text { number }\end{array}$} & \multicolumn{8}{|c|}{ Heavy metal concentrations } & \multicolumn{3}{|c|}{ Textural parameters } & \multirow[b]{2}{*}{ TOC } \\
\hline & Mn & $\mathbf{F e}$ & Co & $\mathbf{N i}$ & $\mathbf{C u}$ & $\mathbf{Z n}$ & $\mathbf{P b}$ & Cd & Sand & Silt & Clay & \\
\hline & \multicolumn{8}{|c|}{$\mathrm{mg} / \mathrm{kg}$} & \multicolumn{4}{|c|}{$\%$} \\
\hline 2 & 583.658 & 58657.879 & 38.721 & 70.252 & 31.756 & 97.963 & 25.614 & 2.397 & 23.74 & 66.78 & 9.48 & 1.25 \\
\hline 5 & 559.107 & 32795.537 & 31.665 & 55.941 & 26.689 & 204.539 & 46.065 & 4.599 & 25.06 & 68.35 & 6.59 & 0.86 \\
\hline 6 & 1803.088 & 29318.380 & 46.606 & 85.494 & 36.338 & 139.601 & 34.008 & 2.986 & 77.42 & 20.74 & 1.84 & 1.46 \\
\hline 7 & 416.477 & 41135.911 & 29.642 & 47.341 & 14.288 & 63.975 & 17.913 & 1.208 & 94.39 & 5.06 & 0.55 & 1.95 \\
\hline 8 & 1300.655 & 81203.242 & 68.579 & 112.765 & 29.847 & 129.130 & 38.809 & 3.351 & 99.89 & 0.11 & 0.00 & 1.72 \\
\hline 9 & 528.130 & 77345.483 & 33.043 & 65.531 & 21.632 & 73.455 & 17.512 & 1.268 & 99.89 & 0.10 & 0.01 & 0.59 \\
\hline 10 & 848.886 & 47388.621 & 36.875 & 66.376 & 49.594 & 101.972 & 17.384 & 2.182 & 99.64 & 0.36 & 0.00 & 1.02 \\
\hline Min & 416.477 & 29318.380 & 29.642 & 47.341 & 14.288 & 63.975 & 17.384 & 1.208 & 23.74 & 0.10 & 0.00 & 0.59 \\
\hline Max & 1803.088 & 81203.242 & 68.579 & 112.765 & 49.594 & 204.539 & 46.065 & 4.599 & 99.89 & 68.35 & 9.48 & 1.95 \\
\hline Average & 862.857 & 52549.293 & 40.733 & 71.957 & 30.021 & 115.805 & 28.186 & 2.570 & 74.29 & 23.07 & 2.64 & 1.26 \\
\hline $\log K d$ & 5.213 & 6.521 & 4.455 & 4.190 & 4.388 & 3.982 & 3.819 & 3.503 & & & & \\
\hline ERL $^{1}$ & & & & 20.900 & 34.000 & 150.000 & 46.700 & 1.200 & & & & \\
\hline ERM $^{1}$ & & & & 51.600 & 270.000 & 410.000 & 218.000 & 9.600 & & & & \\
\hline TEL $^{2}$ & & 20000.000 & & 15.900 & 16.000 & 124.000 & 30.200 & 0.700 & & & & \\
\hline PEL $^{2}$ & & & & 42.000 & 108.000 & 271.000 & 112.000 & 4.200 & & & & \\
\hline SEL $^{2}$ & & 40000.000 & & 75.000 & 110.000 & 820.000 & 250.000 & 10.000 & & & & \\
\hline Continental & & 35000.000 & & 50.000 & 25.000 & 71.000 & 16.000 & 0.098 & & & & \\
\hline $\begin{array}{c}\text { Crust } \\
\text { Average }^{3}\end{array}$ & & & & & & & & & & & & \\
\hline Shale Average ${ }^{4}$ & & 47200.000 & & 68.000 & 45.000 & 95.000 & 20.000 & 0.300 & & & & \\
\hline$* \mathbf{L E L}$ & & & & & & & & & & & & 1.00 \\
\hline$* * \mathbf{S E L}$ & & & & & & & & & & & & 10.00 \\
\hline
\end{tabular}

1 Long et al. (1995); ${ }^{2}$ MacDonald et al. (2000); ${ }^{3}$ McLennan and Taylor (1999); ${ }^{4}$ Turekian and Wedepohi (1961). *LEL and **SEL refer to the lowest, and severe effect levels, respectively (Persaud $\boldsymbol{e t}$ al., 1992). 
In addition to the highest levels of $\mathrm{Fe}, \mathrm{Co}$, and $\mathrm{Ni}$, St $\mathbf{8}$ revealed high values of both $\mathrm{Pb}(38.809 \mathrm{mg} / \mathrm{kg})$ and $\mathrm{Cd}(3.351 \mathrm{mg} / \mathrm{kg})$ as well. Whereas low values of $\mathrm{Zn}(73.455$ $\mathrm{mg} / \mathrm{kg})$ and $\mathrm{Cd}(1.268 \mathrm{mg} / \mathrm{kg})$ were recorded at St 9. Moreover, low concentrations of $\mathrm{Pb}$ $(17.512 \& 17.913 \mathrm{mg} / \mathrm{kg})$ were measured at St 9 \& St 7, respectively. It was noticed that $\mathrm{Mn}$ and Fe were the most abundant heavy metals, while $\mathrm{Cd}$ was the least one (Table 2). The average concentrations of the investigated metals in sediments of Abu-Qir Bay followed the sequence presented as: $\mathrm{Fe}>\mathrm{Mn}>\mathrm{Zn}>\mathrm{Ni}>\mathrm{Co}>\mathrm{Cu}>\mathrm{Pb}>\mathrm{Cd}$.

Comparing heavy metal levels in sediments of Abu-Qir Bay with those of other studies is presented in Table 3. Results showed that, $\mathrm{Mn}$ and Fe metals recorded the highest levels in the present study compared to the mentioned values in Table (3). The exception was only for Mn values reported in Abu-Qir Bay (Faragallah et al., 2004) which were higher than those found in the current study. The observed concentrations of $\mathrm{Cu}$ were lower than those recorded in Abu Qir-Bay (Faragallah et al., 2004), the Egyptian coast along the Mediterranean Sea, the Eastern Harbour and the Western Harbour. On the other hand, they were higher than those recorded in Abu-Qir Bay (Abdel Ghani et al., 2013), eastern coast of Alexandria, eastern Mediterranean coast of Egypt, western part of the Egyptian Mediterranean Sea and El-Max Bay. The recorded concentrations of $\mathrm{Zn}$ were lower than those observed in Abu-Qir Bay (Faragallah et al., 2004), the Eastern Harbour, the Western Harbour and El-Max Bay, while they were higher than those observed in Abu-Qir Bay (Abdel Ghani et al., 2013), eastern coast of Alexandria, eastern Mediterranean coast of Egypt, western part of the Egyptian Mediterranean Sea and Egyptian coast along Mediterranean Sea. Additionally, the $\mathrm{Pb}$ gave concentrations lower than those mentioned in eastern coast of Alexandria, Egyptian coast along Mediterranean Sea, the Eastern Harbour, the Western Harbour and El-Max Bay. However, the upper- mentioned concentrations were higher than those mentioned in Abu-Qir Bay (Abdel Ghani et al., 2013), eastern Mediterranean coast of Egypt and western part of the Egyptian Mediterranean Sea. Markedly, the Cd levels in Abu-Qir exceeded those recorded in the eastern Mediterranean coast of Egypt, western part of the Egyptian Mediterranean Sea, the Eastern Harbour and the Western Harbour. The Cd concentrations were lower than those recorded in Abu-Qir Bay (Abdel Ghani et al., 2013), Egyptian coast along Mediterranean Sea and El-Max Bay.

\section{Evaluation of the pollution environmental impact}

\subsection{Distribution coefficient $(K d)$}

The distribution coefficient is one of the important parameters for evaluating the potential migration of heavy metals in a sediment or the suspended matter that contacted with water column. Quantitatively, the distribution coefficient $K d$ is calculated as the ratio between concentrations of heavy metal in sediments and water according to following equation:

$$
K d=[\operatorname{Metal}(S)] /[\operatorname{Metal}(W)]
$$


Where, $K d(\mathrm{~L} / \mathrm{kg})$ is the distribution coefficient, Metal $(S)$ is the concentration of the heavy metal in sediments $(\mathrm{mg} / \mathrm{kg})$ and Metal $(W)$ is the concentration of the heavy metal in water column $(\mathrm{mg} / \mathrm{L})$. Nabelkova and Kominkova (2012) mentioned that $\mathrm{Kd}$ provides useful information about risk assessment. In case the $\log (K d)>5$, the propability that the metal has affinity to bind in sediments is indicated. While the values in the range $3<\log (K d)<4$ would indicate that the metal is released from the sediment into the water body, and $\log (K d)<3$ indicates prevailing heavy metal in a water body.

Table 3. Comparing heavy metal values in sediment of Abu-Qir Bay with those of other studies in $\mathrm{mg} / \mathrm{kg}$.

\begin{tabular}{|c|c|c|c|c|c|c|c|c|c|}
\hline Location & Mn & $\mathrm{Fe}$ & Co & $\mathbf{N i}$ & $\mathrm{Cu}$ & $\mathrm{Zn}$ & $\mathbf{P b}$ & $\mathrm{Cd}$ & Reference \\
\hline Abu-Qir Bay & $\begin{array}{l}16.477- \\
1803.088\end{array}$ & $\begin{array}{l}29318- \\
81203\end{array}$ & $\begin{array}{c}29.642- \\
68.579\end{array}$ & $\begin{array}{l}47.341- \\
112.765\end{array}$ & $\begin{array}{c}14.288- \\
49.594\end{array}$ & $\begin{array}{l}\text { 63.975- } \\
204.539\end{array}$ & $\begin{array}{c}17.384- \\
46.065\end{array}$ & $\begin{array}{c}1.208- \\
4.599\end{array}$ & $\begin{array}{l}\text { Present } \\
\text { study }\end{array}$ \\
\hline Abu-Qir Bay & $\begin{array}{c}115.030- \\
479.600\end{array}$ & $90-35890$ & ----- & ----- & $\begin{array}{c}10.240- \\
22.850\end{array}$ & $\begin{array}{l}25.230- \\
104.080\end{array}$ & $\begin{array}{l}1.900- \\
16.790\end{array}$ & $\begin{array}{c}0.310- \\
4.890\end{array}$ & $\begin{array}{c}\text { Abdel } \\
\text { Ghani et } \\
\text { al. (2013) }\end{array}$ \\
\hline Abu-Qir Bay & $800-2520$ & $\begin{array}{c}12920- \\
14480\end{array}$ & ----- & ----- & $38-561$ & $\begin{array}{l}118- \\
1779\end{array}$ & ----- & ----- & $\begin{array}{c}\text { Faragallah } \\
\text { et al. } \\
\text { (2004) }\end{array}$ \\
\hline $\begin{array}{l}\text { Eastern coast } \\
\text { of Alexandria }\end{array}$ & $\begin{array}{l}20.880- \\
590.930\end{array}$ & $\begin{array}{c}385- \\
12501\end{array}$ & ---- & -- & $\begin{array}{l}5.480- \\
37.590\end{array}$ & $\begin{array}{c}4.150- \\
198.060\end{array}$ & $\begin{array}{c}16.980- \\
81.750\end{array}$ & ----- & $\begin{array}{l}\text { El Zokm } \\
\text { et al. } \\
(2020)\end{array}$ \\
\hline $\begin{array}{l}\text { Eastern } \\
\text { Mediterranean } \\
\text { coast of Egypt }\end{array}$ & $\begin{array}{l}10.030- \\
119.370\end{array}$ & $\begin{array}{c}50.630- \\
2182.100\end{array}$ & ---- & ----- & $\begin{array}{l}0.550- \\
17.990\end{array}$ & $\begin{array}{l}1.860- \\
14.030\end{array}$ & $\begin{array}{l}8.540- \\
19.250\end{array}$ & $\begin{array}{c}0.100- \\
0.310\end{array}$ & $\begin{array}{l}\text { Khaled et } \\
\text { al. (2009) }\end{array}$ \\
\hline $\begin{array}{l}\text { Western part } \\
\text { of the Egyptian } \\
\text { Mediterranean } \\
\text { Sea }\end{array}$ & $\begin{array}{l}32.270- \\
108.920\end{array}$ & $\begin{array}{l}709.100- \\
1433.900\end{array}$ & -- & & $\begin{array}{c}26.529- \\
33.330\end{array}$ & $\begin{array}{l}26.270- \\
112.070\end{array}$ & $\begin{array}{c}20.670- \\
35.620\end{array}$ & $\begin{array}{c}0.524- \\
0.920\end{array}$ & $\begin{array}{c}\text { Ahdy and } \\
\text { Khaled } \\
\text { (2009) }\end{array}$ \\
\hline $\begin{array}{l}\text { Egyptian coast } \\
\text { along } \\
\text { Mediterranean } \\
\text { Sea }\end{array}$ & $\begin{array}{c}13.480- \\
1384.270\end{array}$ & $\begin{array}{c}124- \\
36868.80 \\
0\end{array}$ & ----- & ----- & $\begin{array}{c}6.940- \\
192.500\end{array}$ & $\begin{array}{l}16.610- \\
166.540\end{array}$ & $\begin{array}{l}49.900- \\
109.770\end{array}$ & $\begin{array}{l}3.700- \\
53.410\end{array}$ & $\begin{array}{l}\text { El Nemr } \\
\text { et al. } \\
(2007)\end{array}$ \\
\hline $\begin{array}{l}\text { The Eastern } \\
\text { Harbou }\end{array}$ & $\begin{array}{c}7.800- \\
188.970\end{array}$ & $10-30240$ & ----- & ----- & $\begin{array}{c}3.800- \\
129.200\end{array}$ & $\begin{array}{c}2.900- \\
206.890\end{array}$ & $\begin{array}{l}1.300- \\
112.090\end{array}$ & $\begin{array}{c}0.300- \\
1.830\end{array}$ & $\begin{array}{c}\text { Abdel } \\
\text { Ghani et } \\
\text { al. (2013) }\end{array}$ \\
\hline $\begin{array}{l}\text { The Western } \\
\text { Harbour }\end{array}$ & $139-317$ & $\begin{array}{l}8819- \\
36140\end{array}$ & ----- & ----- & 39-207 & $\begin{array}{c}58.500- \\
382\end{array}$ & $\begin{array}{c}38- \\
1070\end{array}$ & $\begin{array}{c}0.610- \\
2.440\end{array}$ & $\begin{array}{l}\text { Mostafa } \\
\text { et al. } \\
(2004)\end{array}$ \\
\hline El-Max Bay & $\begin{array}{c}159.310- \\
361.980\end{array}$ & $\begin{array}{l}512.860- \\
2490.590\end{array}$ & ----- & -... & $\begin{array}{c}3.290- \\
47\end{array}$ & $\begin{array}{l}51.350- \\
448.340\end{array}$ & $\begin{array}{l}8.800- \\
88.680\end{array}$ & $\begin{array}{c}2.540- \\
7.540\end{array}$ & $\begin{array}{c}\text { Abdallah } \\
\text { (2008) }\end{array}$ \\
\hline
\end{tabular}

The overall mean of $\log (K d)$ for each metal had been estimated considering the water bodies: $\mathrm{Mn}$ (5.213), Fe (6.521), Co (4.455), Ni (4.190), Cu (4.388), Zn (3.982), Pb (3.819) and $\mathrm{Cd}$ (3.503), Table 2. The following order: $\mathrm{Fe}>\mathrm{Mn}>\mathrm{Zn}>\mathrm{Co}>\mathrm{Cu}>\mathrm{Ni}>$ $\mathrm{Zn}>\mathrm{Pb}>\mathrm{Cd}$ has been observed. Fe showed the highest $\log (K d)$ values in all water bodies, indicating that $\mathrm{Fe}$ is highly stable in sediments. Whereas $\log (\mathrm{Kd})$ for the $\mathrm{Cd}$ 
values indicated that the $\mathrm{Cd}$ is mainly contained in water body, suggesting that the studied water bodies can pose higher risk of $\mathrm{Cd}$. To a certain degree of stability $(\log (K d)>4)$, metals can cause a threat to bottom organisms (Li et al., 2017). Generally, the metals may be released to water under certain conditions, and may endanger the entire aquatic ecosystem, given their toxicity profile (Li et al., 2017).

\subsection{Geo-accumulation index $\left(I_{g e o}\right)$}

Geo-accumulation index $\left(\boldsymbol{I}_{\text {geo }}\right)$ was proposed by Müller (1981) to evaluate the degree of metals contamination in sediments by comparing the concentrations of metal with the pre-industrial levels and calculated using the successive equation (2):

$$
I_{g e o}=\log _{2}\left[C_{n} /(1.5) B_{n}\right]
$$

Where, $C_{n}$ is the metal $(n)$ concentration measured in sediment, $B_{n}$ is the geochemical background value of the metal $(n)$, and factor 1.5 is a factor concerning the background level variations due to lithogenic impacts. In the present study, the average shale values stated by Turekian and wedepohl (1961) were used as the background levels of heavy metals. Seven classes of $\left(\boldsymbol{I}_{g e o}\right)$ index ranging from 0-6 were classified by Müller (1981), and organized from the uncontaminated to the highly contaminated sediments as described in Table (4).

It can be deduced from Tables ( $4 \& 5$ ) that, with reference to Müller scale, most of the $I_{g e o}$ values of $\mathrm{Cd}$ in surface sediments through all study areas were between 1 and 3 $\left(1<I_{\text {geo }}<3\right.$; class 3$)$, indicating that those sites are moderately to strongly polluted with $\mathrm{Cd}$. On the other hand, $I_{\text {geo }}$ values of $\mathrm{Ni}, \mathrm{Cu}, \mathrm{Zn}$, and $\mathrm{Pb}$ in surface sediments of most study areas were apparently lower than $0\left(I_{\text {geo }}<0\right.$; class 0$)$, indicating a practically unpolluted status.

Table 4. Classification of $I_{g e o}$ (Müller, 1981). The modified degree of contamination $\left(m C_{d}\right)$ (Abrahim \& Parker, 2007), and potential ecological risk index, $R I$ (Hakanson, 1980).

\begin{tabular}{|c|c|c|c|c|c|c|c|}
\hline$I_{g e o}$ & $\begin{array}{l}I_{\text {geo }} \\
\text { class }\end{array}$ & $\begin{array}{c}\text { Designation of } \\
\text { sediment quality }\end{array}$ & $m C_{d}$ & $\begin{array}{l}m C_{d} \\
\text { class }\end{array}$ & $\begin{array}{c}\text { Contamination } \\
\text { degree }\end{array}$ & $R I$ values & Risk Intensity \\
\hline$<0$ & 0 & Unpolluted & $<1.5$ & 0 & Unpolluted & $R I<150$ & $\begin{array}{c}\text { Low ecological } \\
\text { risk }\end{array}$ \\
\hline $0-1$ & 1 & $\begin{array}{l}\text { Unpolluted to } \\
\text { moderately } \\
\text { polluted }\end{array}$ & $1.5 \leq m C_{d}<2$ & 1 & Slightly polluted & $\begin{array}{c}150 \leq R I< \\
300\end{array}$ & $\begin{array}{c}\text { Moderate } \\
\text { ecological risk }\end{array}$ \\
\hline $1-2$ & 2 & Moderately polluted & $2 \leq m C_{d}<4$ & 2 & $\begin{array}{l}\text { Moderately } \\
\text { polluted }\end{array}$ & $\begin{array}{c}300 \leq R I< \\
600\end{array}$ & $\begin{array}{l}\text { Considerable } \\
\text { ecological risk }\end{array}$ \\
\hline $2-3$ & 3 & $\begin{array}{l}\text { Moderately to } \\
\text { strongly polluted }\end{array}$ & $4 \leq m C_{d}<8$ & 3 & $\begin{array}{l}\text { Moderately to } \\
\text { heavily polluted }\end{array}$ & $R I>600$ & $\begin{array}{c}\text { Very high } \\
\text { ecological risk }\end{array}$ \\
\hline $3-4$ & 4 & Strongly polluted & $8 \leq m C_{d}<16$ & 4 & Heavily polluted & & \\
\hline $4-5$ & 5 & $\begin{array}{c}\text { Strongly to } \\
\text { extremely polluted }\end{array}$ & $16 \leq m C_{d}<32$ & 5 & Severely polluted & & \\
\hline$>5$ & 6 & Extremely polluted & $\geq 32$ & 6 & Extremely polluted & & \\
\hline
\end{tabular}




\subsection{Pollution Loading Index (PLI)}

Pollution loading index $(P L I)$ was proposed by Tomlinson et al. (1980) and Satyanarayana et al. (1994) to evaluate the integrated pollution status of synergetic groups for a particular station. If the $P L I$ value $>1$, a polluted condition is indicated, while $P L I<1$ would signify no metal pollution. This parameter is expressed in the following equation:

$$
P L I=\left(C F_{1} \times C F_{2} \times C F_{3} \times \ldots \ldots . . . \times C F_{n}\right)^{1 / n}
$$

Where, $n$ is the number of selected metals, and $C F$ is the contamination factor. $C F$ can be calculated from the following equation (4):

$$
C F=\frac{\text { Metal concentration in the sediments }}{\text { Background value of the metal }}
$$

The contamination factor $(C F)$ is used to evaluate the anthropogenic input of metals to sediment. The average shale value is the background concentration of the selected metal as given by Turekian and wedepohl (1961).

The calculated PLI values for the studied metals are listed in Table (5) and represented in Figure (3). Most of $P L I$ values of surface sediments fall above $1(P L I>1)$, indicating that they were polluted sites. On the other hand, St 7 was an unpolluted site $(P L I<1)$.

Table 5. Evaluation of heavy metals pollution in sediments from Abu-Qir Bay based on

\begin{tabular}{|c|c|c|c|c|c|c|c|c|c|}
\hline \multirow{2}{*}{$\begin{array}{l}\text { Station } \\
\text { number }\end{array}$} & \multicolumn{5}{|c|}{$I_{g e o}$} & \multirow{2}{*}{ PLI } & \multirow{2}{*}{$m C_{d}$} & \multirow{2}{*}{$R I$} & \multirow{2}{*}{$M E R M-Q$} \\
\hline & $\mathrm{Ni}$ & $\mathrm{Cu}$ & $\mathrm{Zn}$ & $\mathrm{Pb}$ & $\mathrm{Cd}$ & & & & \\
\hline 2 & -0.54 & -1.09 & -0.54 & -0.23 & 2.41 & 1.50 & 2.41 & 255.79 & 0.42 \\
\hline 5 & -0.87 & -1.34 & 0.52 & 0.62 & 3.35 & 2.06 & 4.24 & 480.64 & 0.47 \\
\hline 6 & -0.25 & -0.89 & -0.03 & 0.18 & 2.73 & 1.91 & 3.04 & 318.87 & 0.52 \\
\hline 7 & -1.11 & -2.24 & -1.16 & -0.74 & 1.43 & 0.88 & 1.32 & 131.06 & 0.27 \\
\hline 8 & 0.14 & -1.18 & -0.14 & 0.37 & 2.90 & 2.01 & 3.36 & 357.77 & 0.63 \\
\hline 9 & -0.64 & -1.64 & -0.96 & -0.78 & 1.49 & 1.06 & 1.46 & 139.16 & 0.35 \\
\hline 10 & -0.62 & -0.44 & -0.48 & -0.79 & 2.28 & 1.49 & 2.26 & 234.05 & 0.41 \\
\hline Min & -1.11 & -2.24 & -1.16 & -0.79 & 1.43 & 0.88 & 1.32 & 131.06 & 0.27 \\
\hline Max & 0.14 & -0.44 & 0.52 & 0.62 & 3.35 & 2.06 & 4.24 & 480.64 & 0.63 \\
\hline Average & -0.55 & -1.26 & -0.40 & -0.19 & 2.37 & 1.56 & 2.58 & 273.91 & 0.44 \\
\hline
\end{tabular}

$$
I_{\text {geo }}, P L I, m C_{d}, R I_{y} \text { and } M E R M-Q \text { indices. }
$$




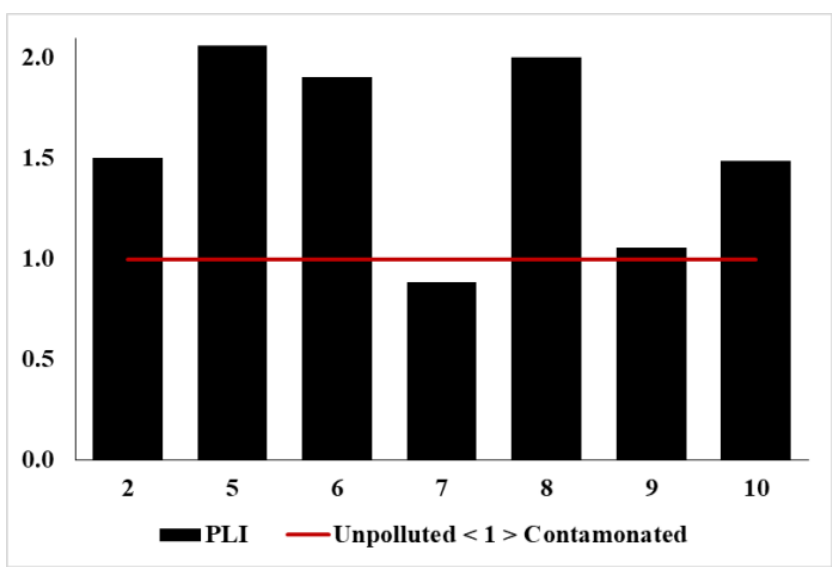

Figure 3. Pollution Loading Index (PLI) of surface sediments from Abu-Qir Bay.

\subsection{Assessment according to modified degree of contamination ( $\left.m C_{d}\right)$}

Abrahim and Parker (2007) suggested a modified degree of contamination $\left(m C_{d}\right)$ to evaluate the overall contamination of sediment sample in the presence of multimetal rather than the contamination caused by one metal ion for one sample. According to equation (5) $m C_{d}$ can be calculated.

$$
m C_{d}=\frac{\sum_{i=1}^{n} c_{f}^{i}}{n}
$$

Where, $n$ is the number of selected metals and $C_{f}^{i}$ refers to the contamination factors proposed by Hakanson (1980). Based on $m C_{d}$ values, seven degrees of contamination were classified by Abrahim and Parker (2007) as shown in Table (4). The $m C_{d}$ values of the selected metals through all study areas are represented in Table (5) and Figure (4). The values of $m C_{d}$ for $\mathrm{Ni}, \mathrm{Cu}, \mathrm{Zn}, \mathrm{Pb}$, and $\mathrm{Cd}$ ranged between 1.32 and 4.24 , reflecting a low to moderate degree of contamination.

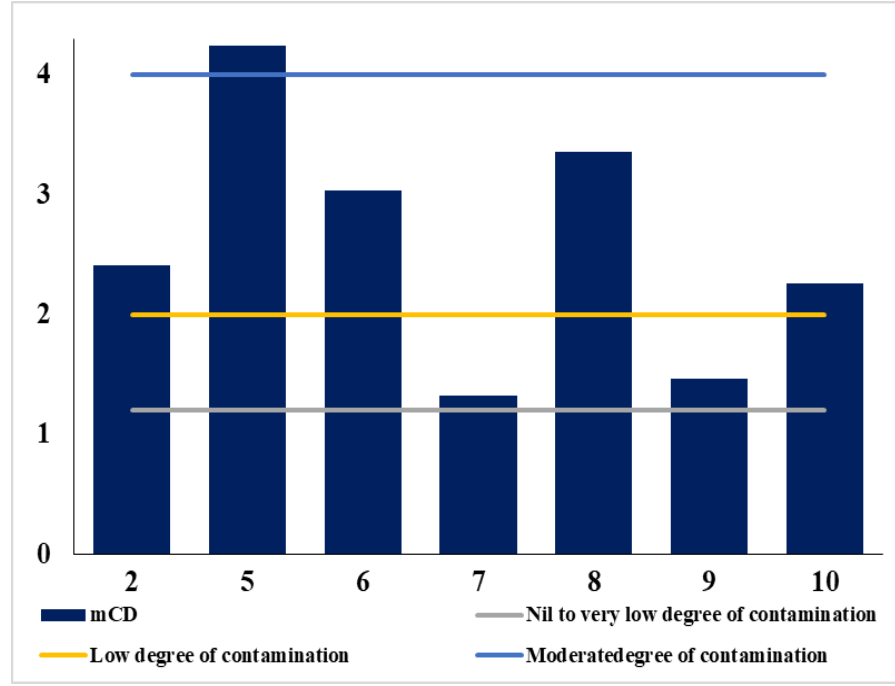

Figure 4. Modified degree of contamination $\left(m C_{d}\right)$ index of surface sediments from Abu-Qir Bay. 


\subsection{Assessment according to ecological risk index $(R I)$}

Hakanson (1980) proposed the ecological risk index $(R I)$ to evaluate the ecological risks for aquatic organisms. According to the equations (6) and (7), the ecological risk index $(R I)$ was calculated as a sum of five heavy metals $(\mathrm{Ni}, \mathrm{Cu}, \mathrm{Zn}, \mathrm{Pb}$, and $\mathrm{Cd}$ ):

$$
\begin{gathered}
E_{r}^{i}=T_{r}^{\tilde{i}} \times C_{F}^{\tilde{i}} \\
R I=\sum E_{r}^{i}
\end{gathered}
$$

Where $R I$ is the sum of the potential ecological risk factor $\left(E_{r}^{i}\right), T_{r}^{i}$ is the metal toxic response factor for a given metal, and $C_{F}^{i}$ refers to the contamination factor. The calculated $R I$ values for $\mathrm{Ni}, \mathrm{Cu}, \mathrm{Zn}, \mathrm{Pb}$ and $\mathrm{Cd}$ in all study areas are listed in Table (5) and shown in Figure (5). Those metals presented moderate ecological risk $(150 \leq \mathrm{RI}<$ 300) for all studied sites, except for St 5 and St 8 that showed a considerable ecological risk $(R I>300)$. The values for each investigated metal followed the sequence: $\mathrm{Zn}=\mathrm{Ni}$ $=1<\mathrm{Cr}=2<\mathrm{Cu}=\mathrm{Pb}=5$.

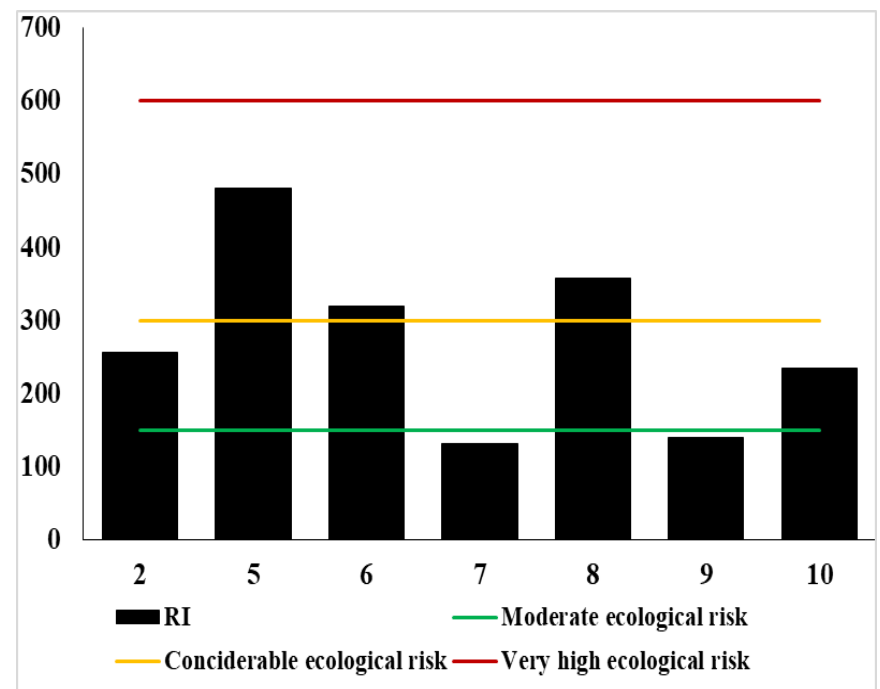

Figure 5. Potential risks $(R I)$ index of surface sediments from Abu-Qir Bay.

\subsection{Mean effect range median quotient $(M E R M-Q)$}

The mean ERM quotient $(M E R M-Q)$ is a method used to evaluate the possible biological effects of all the investigated metals and PAHs by comparing their observed concentrations with their limit concentrations and calculating the values using the equation (8) suggested by Long et al. (1998):

$$
M E R M-Q=\Sigma\left(C_{i} / E R M_{i}\right) / n
$$

Where, $C_{i}$ refers to sediment concentration of metal $i, E R M_{i}$ is the effect rang medium of metal $i$, and $n$ refers to number of metals. The $E R M_{i}$ values for each investigated metal were: $\mathrm{Ni}=51.0, \mathrm{Cu}=270, \mathrm{Zn}=410, \mathrm{~Pb}=218$ and $\mathrm{Cd}=9.60$. 
According to Long et al. (2000) and Gao and Chen (2012), $M E R M-Q$ can be classified into four categories: $M E R M-Q<0.1$ has $9 \%$ probability of being toxic (low), between 0.11-0.51 represents $21 \%$ probability of being toxic (low to medium), and between the range 0.51-1.5 indicates $49 \%$ probability of being toxic (high- medium). While $M E R M-Q>1.5$ indicates $74 \%$ of toxicity (high-priority sites). The calculated $M E R M-Q$ values for the sampling sites for $\mathrm{Ni}, \mathrm{Cu}, \mathrm{Zn}, \mathrm{Pb}$, and $\mathrm{Cd}$ varied from 0.27 to 0.63 and the average value was 0.44 (Figure $6 \&$ Table 5). Based on this classification, all samples had low to medium toxicity ( $21 \%$ probability of being toxic).

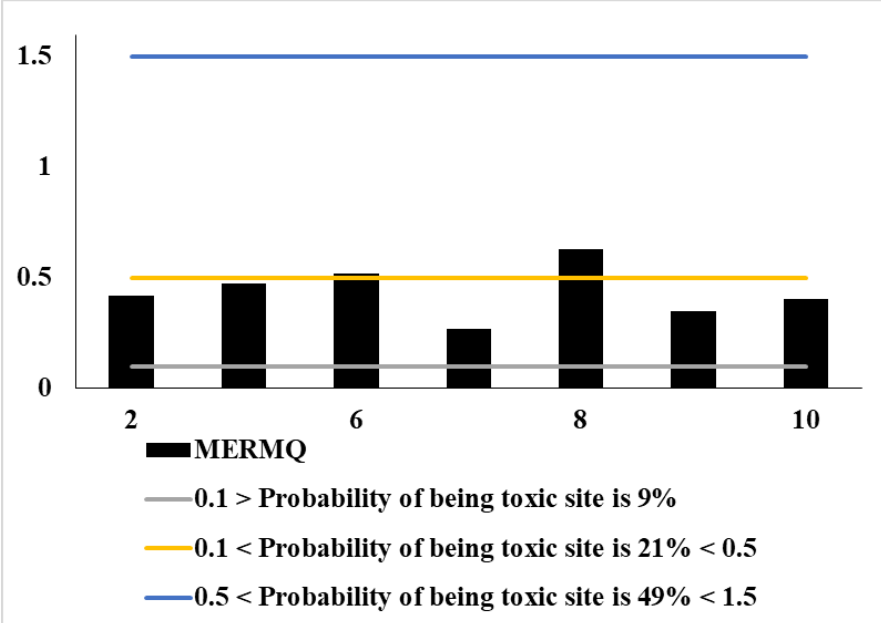

Figure 6. Mean ERM quotient (MERM-Q) index of surface sediments from Abu-Qir Bay.

Comparing the $M E R M-Q$ calculated values with $E R M$ individual value, one can say that, the $M E R M-Q$ is a more effective index for reducing the large data to a single number to assess the extent of each metal. In general, according to the results of $I_{\text {geo }}$, $P L I, m C_{d}$, and $R I$ indices as well as $M E R M-Q$, a considerable and intense heavy metals pollution of sediments through all study areas was detected. This may be due to human activities; industrial effluents of Petrojet company, paper and fertilizer factories, Abu-Qir EPS, and fishing boats, as well as the outlet of Lake Edku (Boughaz El-Maddya) which contains different types of pollutants as pesticides, humic acids, and trace metals.

\section{Application of principal component analysis (PCA) and redundancy analysis (RDA)}

Principal components analysis (PCA) is a useful tool used to understand the distribution and the sources of heavy metals and their relationship (Varol, 2011). In the present research, PCA was conducted on basis of the determined concentrations of heavy metals in seawater, SPM and sediments with varimax-rotation. The PCA results are represented in Table (6), the PC1 with a variance of $31.06 \%$ exhibited a significant positive correlation of the congeners $\mathrm{Fe}(0.92)$, Co (0.80), and $\mathrm{Ni}(0.81)$ of seawater, 
indicating a common source that may be due to the exogenous discharge (Mao, 2013). The PC2 of the variance $23.70 \%$ exhibited a correlation between Mn (0.94), Ni (0.83), and $\mathrm{Cu}(0.72)$ of SPM as well as $\mathrm{Zn}(0.72)$ of sediment samples, that indicated a common source as well as the sedimentation-re-suspension process. The mentioned metals either in particulate or sediments were strongly affected by the alkalinity of seawater (0.75). The PC3 results also indicated a good positive correlation between $\mathrm{Mn}(0.73), \mathrm{Cu}(0.90)$, $\mathrm{Zn}(0.71)$, and $\mathrm{Pb}(0.72)$ of seawater samples. PC4 and PC5 of variance $12.69 \%$ and 8.09 $\%$, respectively showed a good correlation between $\mathrm{Cd}(0.74)$ of seawater samples and OOM (0.87) as well as between $\mathrm{Cd}(0.63)$ of particulate samples and TOC (0.74\%). In the pollution assessment, Cd had higher $I_{g e o}$ values $\left(1<I_{g e o}<3\right.$; class 3$)$, indicating that these sites were moderately to strongly contaminated with $\mathrm{Cd}$. Therefore, $\mathrm{Cd}$ may be originated from natural sources with contributions from agricultural wastes (EI-Nemr \& El-Said, 2017).

Table 6. Rotated components matrix and water quality index for studied parameters of Abu-Qir Bay.

\begin{tabular}{|c|c|c|c|c|c|c|}
\hline \multicolumn{4}{|c|}{ PCA } & \multirow{2}{*}{ Variables and loading values } & \multicolumn{2}{|c|}{$\begin{array}{c}\text { Water Quality } \\
\text { Index }\end{array}$} \\
\hline Component & Total & $\begin{array}{l}\text { Variance } \\
(\%)\end{array}$ & $\begin{array}{c}\text { Cumulative } \\
(\%)\end{array}$ & & St & WQI \\
\hline PCA1 & 10.87 & 31.06 & 31.06 & $\begin{array}{l}\text { Fe-w (0.92), Co-w (0.80), and Ni-w } \\
(0.81)\end{array}$ & 2 & 0.460161 \\
\hline PCA2 & 8.29 & 23.70 & 54.75 & $\begin{array}{l}\text { Mn-p (0.94), Ni-p (0.83), Cu-p (0.72), } \\
\text { and Zn-s (0.72) \& alkalinity (0.75). }\end{array}$ & 3 & 0.060052 \\
\hline PCA3 & 7.07 & 20.20 & 74.95 & $\begin{array}{l}\mathrm{Mn}-\mathrm{w}(0.73), \mathrm{Cu}-\mathrm{w}(0.90), \mathrm{Zn}-\mathrm{w}(0.71) \text {, } \\
\text { and } \mathrm{Pb}-\mathrm{w}(0.72) .\end{array}$ & 4 & 0.707431 \\
\hline PCA4 & 4.44 & 12.69 & 87.64 & Cd-w (0.74) \& OOM (0.87) & 5 & 0.160326 \\
\hline PCA5 & 2.83 & 8.09 & 95.73 & Cd-p (0.63) \& TOC (0.74) & 6 & 0.322984 \\
\hline PCA6 & 1.49 & 4.27 & 100.00 & Cd-s (0.63) & 7 & -0.277910 \\
\hline & & & & & 8 & -0.755040 \\
\hline & & & & & 9 & -0.445220 \\
\hline & & & & & 10 & -0.232790 \\
\hline
\end{tabular}

To investigate the relationship between the environmental factors and the distribution of heavy metals in sediment, the RDA was used. The result of RDA for seawater and particulate matter as well as for sediment are represented in Fig. (7A \& 7B). The angle between the heavy metal and environmental factors reflects their relationship. Metals in seawater such as $\mathrm{Mn}, \mathrm{Fe}, \mathrm{Co}, \mathrm{Ni}, \mathrm{Cu}, \mathrm{Zn}, \mathrm{Pb}, \mathrm{Cd}$ and temperature, salinity, as well as TDS can be considered as significant parameters that reflect the water quality of Abu-Qir Bay coastal waters. Strong positive correlation of metals ( $\mathrm{Mn}, \mathrm{Fe}, \mathrm{Co}, \mathrm{Ni}, \mathrm{Cu}$, $\mathrm{Zn}, \mathrm{Pb}$, and $\mathrm{Cd}), \mathrm{pH}, \mathrm{DO}$ and T.alk. in particulate matter was also observed. The concentration of $\mathrm{Fe}$ in sediment was positively correlated to TOC and fine sand \% (Fig. 7B) which accorded with the result of $K d$, whereas the RDA analysis explained that $\mathrm{Zn}$, $\mathrm{Pb}$, and $\mathrm{Cd}$ contents in sediments are strongly related. 

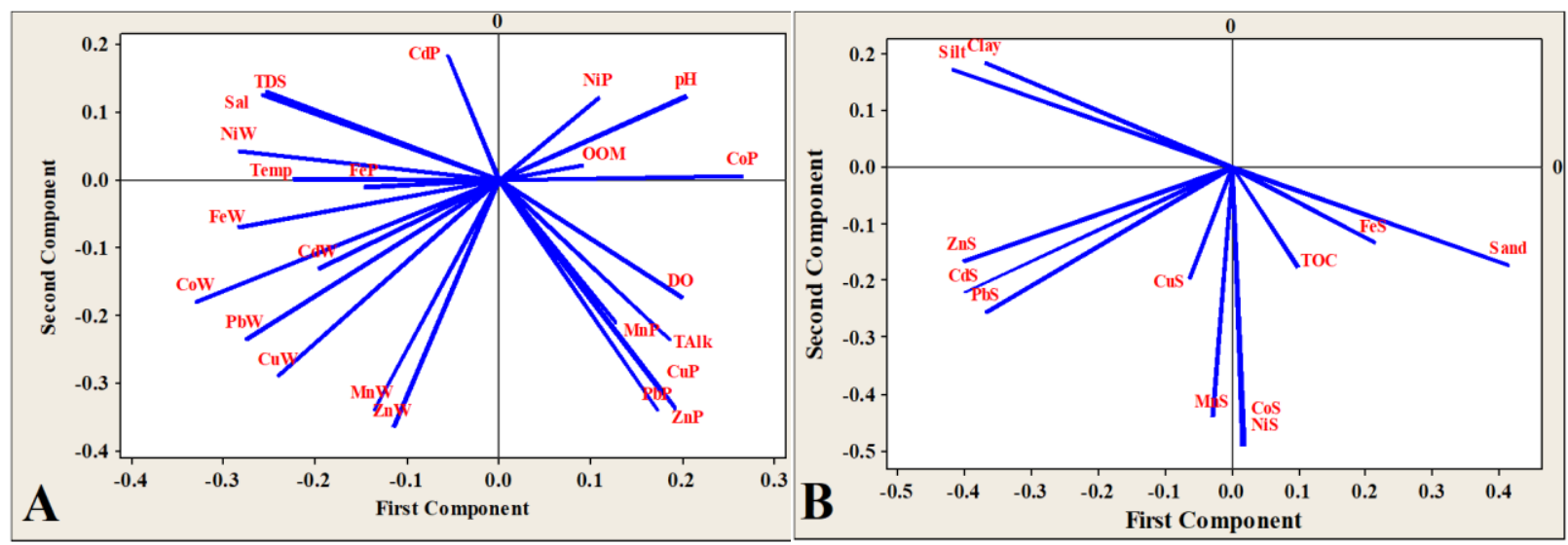

Fig. 7. RDA diagram between heavy metals and: A) Seawater variables; W: dissolved \& P: particulate and B) sediment variables; $S$.

\section{Water quality index (WQI)}

In the current study, principle component analysis was employed to assess the water quality index $(W Q I)$ at each station and detect the hot spot stations. WQI can be calculated according to equation (9)

$$
W Q I=\sum_{n=1}^{n}\left(\frac{\lambda_{n}}{\Sigma \lambda}\right) \times P C_{n}
$$

Where, $n$ and $\lambda_{n}$ refer to the number and the Eigenvalues of effective components, respectively. Whereas $\Sigma \lambda$ is the sum of the Eigenvalues and $P C_{n}$ that refers to the $n$ critical principal component scores (MacDonald $\boldsymbol{e t}$ al., 2003). The data of water quality index (WQI) of Abu-Qir Bay are shown in Table (6). They depicted that, St 7 to St 10 were relatively good and varied between -0.23 at St $\mathbf{1 0}$ and -0.75 at St $\mathbf{8}$ meanwhile, water quality index of the other stations (St 2 to St 6) showed that they were slightly polluted to different degrees (0.060-0.707). Thus, they could be considered as hot spots. St 2 exists in front of Abu-Qir city and can be affected by human activities and domestic effluents. While St $\mathbf{3}$ to St $\mathbf{5}$ are exposed to pollution caused by the activities of gas production (Petrojet company) and Abu-Qir EPS. St 6 is located at the outlet of Lake Edku (Boughaz El-Maddya) which contains a different type of hazard materials as pesticides, humic acids, and trace metals as well as fishing boats.

\section{CONCLUSION}

The marine ecosystem is threatened by the discharge of industrial effluents which affects the sustainability of living organisms and hence public health. Identification of the sources of the heavy metals ( $\mathrm{Mn}, \mathrm{Fe}, \mathrm{Co}, \mathrm{Ni}, \mathrm{Cu}, \mathrm{Zn}, \mathrm{Pb}$, and $\mathrm{Cd}$ ) as well as their distribution between water body and sediment of Abu-Qir Bay area were studied. The present study provided a detailed on heavy metal concentrations in seawater, SPM, and sediment. The level of contamination in Abu-Qir Bay and their ecological risks to aquatic 
organisms showed that the anthropogenic activities are the fundamental source of heavy metals in Abu-Qir Bay. However, among the eight examined heavy metals in the surveyed area, the content of $\mathrm{Cd}$ was the highest in sediment and according to PCA, Cd may be originated from natural sources with some effects from agricultural wastes.

\section{REFERENCES}

Abdallah, M.A.M. (2008). Trace metal behavior in Mediterranean climate coastal bay: El-Mex Bay, Egypt and its coastal environment. Global Journal of Environmental Research, 2(1): 23-29.

Abdel Ghani, S.; El Zokm, G.; Shobier, A.; Othman, T. and Shreadah, M. (2013). Metal pollution in surface sediments of Abu-Qir Bay and Eastern Harbour of Alexandria, Egypt. Egyptian Journal of Aquatic Research, 39: 1-12.

Abdullah, M.I. and Royle, L.G. (1974). A study of the dissolved and particulate trace elements in the Bristol Channel. Journal of the Marine Biological Association of the United Kingdom, 54: 581-597.

Abrahim, G.M.S. and Parker, R.J. (2007). Assessment of heavy metal enrichment factors and the degree of contamination in marine sediments from Tamaki Estuary, Auckland, New Zealand. Environmental Monitoring and Assessment, 136: 227238.

Ahdy, H. and Khaled, A. (2009). Heavy metals contamination in sediments of the western part of Egyptian Mediterranean Sea. Australian Journal of Basic and Applied Sciences, 3 (4): 3330-3336.

Alam El-Din, K.A. and Al-Hogaraty, E.E. (2001). Modeling the seasonal variability of density current in Abu-Qir Bay. Bull. Nat. Inst. of Oceanogr. \& Fish., ARE., 27: 275-292.

ANZECC/ARMCANZ (2000). Australian and New Zealand guidelines for fresh and marine waters. National Water Quality Management Strategy Paper No 4, Australian and New Zealand environment and conservation council/agriculture resource management council of Australia and New Zealand, Canberra.

APHA (1995) WPCF, Standard Methods for the Examination of Water and Wastewater. American Public Health Association/American, Water Works Association/Water Environment Federation, Washington DC.

Boran, M. and Altınok, I. (2010). A Review of Heavy Metals in Water, Sediment and Living Organisms in the Black Sea. Turkish Journal of Fisheries and Aquatic Sciences, 10: 565-572.

Cao, Q.; Wang, H.; Li, Y.; et al. (2018). The national distribution pattern and factors affecting heavy metals in sediments of water systems in China. Soil and Sediment Contamination: An International Journal, 27(2): 79-97. 
Das, J.; Das, S.N. and Sahoo, R.K. (1997). Semidiurnal variation of some physicochemical parameters in the Mahanadi estuary, east coast of India. Indian Journal of Geo-Marine Sciences (IJMS), 26: 323-326.

Dumcius, A.; Paliulis, D. and Kozlovska-Kedziora, J. (2011). Selection of investigation methods for heavy metal pollution on soil and sediments of water basins and river bottom review. Ekologija., 57(1): 30-38.

El Nemr, A.M.; El-Said, G.F. (2017). Assessment and Ecological Risk of Heavy Metals in Sediment and Molluscs from the Mediterranean Coast. Water Environment Research, 89(3): 195-210.

El Nemr, A.M.; El Sikaily, A. and Khaled, A. (2007). Total and leachable heavy metals in muddy and sandy sediments of the Egyptian coast along Mediterranean Sea. Environmental Monitoring and Assessment, 129: 151-168.

El Zokm, G.M.; Ibrahim, M.I.A.; Mohamed, L.A. and El-Mamoney, M. (2020). Critical geochemical insight into Alexandria coast with special reference to diagnostic ratios (TOC/TN \& $\mathrm{Sr} / \mathrm{Ca}$ ) and heavy metals ecotoxicological hazards. Egyptian Journal of Aquatic Research, 46: 27-33.

FAO (1976). Manual of Methods in Aquatic Environmental Research, Part I: Permanganate Value (Oxidizability) of Organic Matter in Natural Waters. FAO Fisheries Technical Paper No. 137, 169-174.

Faragallah, H.M. (2004). Chemical Fractionation of Phosphorous and some Heavy Metals in Suspended Matter in Water Column and in Sediment in Abu-Qir Bay Egypt. Ph.D. Thesis, Faculty of Science, Alexandria University, Egypt.

Folk, R.L. (1974). Petrology of Sedimentary Rocks. Austin, Tex: Hemphill Pub. Co., pp. 182.

Folk, R.L. (1980). Petrology of sedimentary rocks. Hemphill Company, Austin, USA.

Gao, X. and Chen, C.T.A. (2012). Heavy metal pollution status in surface sediments of the coastal Bohai Bay. Water Research, 46(6): 1901-1911.

Gao, Y.; Oshita, K.; Lee, K.-H.; Oshima, M. and Motomizu, S. (2002). Development of column-pretreatment chelating resins for matrix elimination/multi-element determination by inductively coupled plasma-mass spectrometry. Analyst, 127: 1713-1719.

Gaudette, H.E.; Flight, W.R.; Oner, L. and Folger, D.W. (1974). An inexpensive titration method for the determination of organic carbon in recent sediments. Journal of sedimentary petrology, 44 (1): 249-253.

Grasshoff, K.; Kremling, K. and Ehrhardt, M. (1999). Methods of Seawater Analysis, third ed. Wiley-VCH Verlag GmbH, Weinheim.

Hakanson, L. (1980). An ecological risk index for aquatic pollution control: a sedimentological approach. Water Research, 14(8): 975-1001. 
Khaled, A.; El Nemr, A.; El Sikaily, A. and Sarraf, W. (2009). Evaluation of trace metal concentrations in sediments samples from eastern Mediterranean coast of Egypt. Egyptian Journal of Aquatic Research, 31(1): 99-119.

Li, Y.; Liu, F.; Zhou, X.; Wnag, X.; Liu, Q.; Zhu, P.; Zhang, L.; Sun, C. (2017). Distribution and Ecological Risk Assessment of Metals in Sediments in Chinese Collapsed Lakes. Polish Journal of Environmental Studies, 26(1): 181-188.

Liu, J.; Li, Y.; Zhang, B.; Cao, J.; Cao, Z. and Domagalski, J. (2009). Ecological risk of heavy metals in sediments of the Luan River source water. Ecotoxicology, 18: 748758.

Long, E.R.; Field, L.J. and MacDonald, D.D. (1998). Predicting toxicity in marine sediments with numerical sediment quality guidelines. Environ. Toxicol. Chem., 17: 714-727.

Long, E.; Macdonald, D.; Smith, S. and Calder, F. (1995). Incidence of adverse biological effects within ranges of chemical concentration in marine and estuarine sediments. Environ. Manage., 19: 81-97.

Long, E.R.; MacDonald, D.D.; Severn, C.G. and Hong, C.B. (2000). Classifying the probabilities of acute toxicity in marine sediments with empirically-derived sediment quality guidelines. Environmental Toxicology and Chemistry, 19: 25982601.

MacDonald, D.D.; Ingersoll, C.G. and Berger, T.A. (2000). Development and evaluation of consensus-based sediment quality guidelines for freshwater ecosystem. Arch. Environ. Contam. Toxicol., 39: 20-31.

MacDonald, D.D.; Smorong, D.E.; Levy, D.A.; Swain, L.; Caux, P.Y. and Kemper, J.B. (2003). Canadian Water Quality Guidelines for the Protection of Aquatic Life. Canadian Council of Ministers of the Environment.

Mao, L.; Mo, D.; Guo, Y.; Fu, Q.; Yang, J. and Jia, Y. (2013). Multivariate analysis of heavy metals in surface sediments from lower reaches of the Xiangjiang River, southern China. Environ Earth Sci, 69: 765-771.

Masindi, V. and Muedi, K.L. (2018). Environmental contamination by heavy metals, Chapter 7, pp. 115-133, DOI: 10.5772/intechopen.76082.

McLennan, S.M. and Taylor, S.R. (1999). Earth's continental crust. In: Encyclopedia of Geochemistry. Marshall, C.P. \& Fairbridge, R.W. (Eds.). Kluwer Academic Publishers, Dordrecht, pp. 145-150.

Mostafa, A.; Barakat, A.; Qian, Y. and Wade, T. (2004). An overview of metal pollution in the Wester Harbour of Alexandria, Egypt. Soil \& Sediment Contamination, 13: 299-311.

Müller, G. (1981). The Heavy Metal Pollution of the Sediments of Neckars and its Tributary, A stocktaking. Chem. Zeit., 105: 157-164. 
Nabelkova, J. and Kominkova, D. (2012). Trace Metals in the Bed Sediment of Small Urban Streams. The Open Environmental and Biological Monitoring Journal, 5(1): 48-55.

Oregioni, B. and Aston, S.R. (1984). The determination of selected trace metals in marine sediments by flameless/flame atomic absorption spectrophotometry IAEA Monaco Laboratory, Report Cited from Reference Method in Pollution Studies N. 38. UNEP, 1986 .

Pekey, H.; Karakas, D.; Ayberk, S.; Tolun, L. and Bakoğlu, M. (2004). Ecological risk assessment using trace elements from surface sediments of Ízmit Bay (Northeastern Marmara Sea) Turkey. Marine Pollution Bulletin, 48: 946-953.

Persaud, D.; Jaagumagi, R. and Hayton, A. (1992). Guidelines for the protection and management of aquatic sediment quality in Ontario. ISBN 0-7729-9248-7. Ontario Ministry of the Environment, Water Resources Branch, Toronto.

Radwan, A.A. (1996), Hydrographic Structure and heat budget of Abu Qir Bay. MsC Thesis, Fact. of Sci. Alex. Uni. 106pp

Salati, S. and Moore, F. (2010). Assessment of heavy metal concentration in the Khoshk River water and sediment, Shiraz, Southwest Iran. Environ. Monit. Assess., 164: 677-689.

Satyanarayana, D.; Panigrahy, P.K. and Sahu, S.D. (1994). Metal pollution in harbor and coast sediments of Visakhapatnam, east coast of India. Indian J. Mar Sci., 23 (1): $52-54$.

Sun, X.; Li, B.-S.; Liu, X.-L. and Li, C.-X. (2020). Spatial Variations and Potential Risks of Heavy Metals in Seawater, Sediments and Living Organisms in Jiuzhen Bay, China. Journal of Chemistry, 2020: Article ID 7971294, 13 pages.

Tomlinson, D.L.; Wilson, J.G.; Harris, C.R. and Jeffery, D.W. (1980). Problems in the assessment of heavy-metal levels in estuaries and the formation of a pollution index. Helgoland Marine Research 33: 566-575.

Turekian, K.K. and Wedepohl, K.H. (1961). Distribution of the elements in some major units of the Earth's crust. Geological Society of America Bulletin, 72: 175-192.

Tylmann, W.; Lysek, K.; Kinder, M.; Pempkowiak, J. (2011). Regional pattern of heavy metal content in Lake sediments in Northern Poland. Water Air Soil Pollut., 216: 217-228.

US EPA (2006). National recommended water quality criteria.

Varol, M. (2011). Assessment of heavy metal contamination in sediments of the Tigris River (Turkey) using pollution indices and multivariate statistical techniques. Journal of Hazardous Materials, 195: 355-364.

World quality criteria (WQC). A Report of the Committee on Water Quality Criteria, p. 593, NAS, Washington, DC (1972). 
Zakaria, H.Y.; Radwan, A.A. and Said, M. (2019). Zooplankton community characteristics of the different water types in Abu Qir Bay, Alexandria, Egypt. The Egyptian Journal of Aquatic Research 45(2): 131-138.



الغرض من هذه الدر اسة هو تحديد مصادر المعادن الثقيلة وتوزيعها بين المسطح المائي والرواسب في منطقة خليج أبوقير. تم تقييم مستوى المعادن الثقيلة ( Mn ،




في $\mathrm{Fe}>\mathrm{Mn}>\mathrm{Zn}>\mathrm{Ni}>\mathrm{Co}>\mathrm{Cu}>\mathrm{Pb}>\mathrm{Cd}$ و في $\mathrm{Zn}>\mathrm{Mn}>\mathrm{Pb}>\mathrm{Cu}>\mathrm{Ni}>\mathrm{Co}>\mathrm{Cd}$

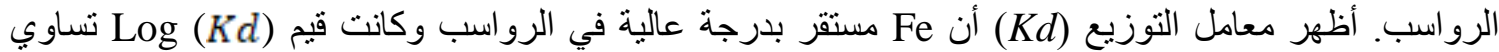
6.521 في جميع water bodies. تم حساب معامل التز اكم الجغر افي (Igeo) ، ومعامل حمل التلوث (PLI) ، ودرجة التلوث المعدلة (mC $)$ ، ومؤشر المخاطر البيئية المحتملة (RI) ، ومتوسط حاصل المدي الفعال كانت قيم $. M E R M-Q$ معتدل إلى قوي بـ Cd. تراوحت قيم تلوث منخفضة إلى متوسطة. قدمت المعادن المدروسة مخاطر بيئية معتدلة (





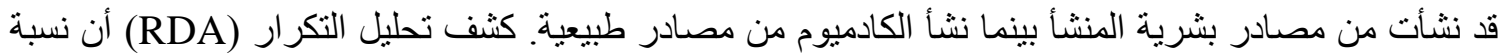

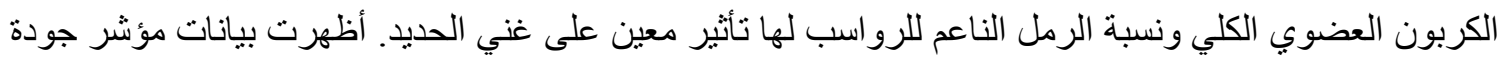

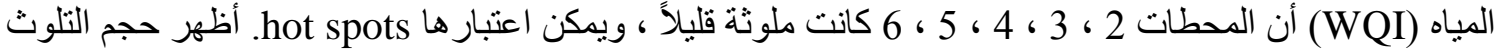
و المخاطر البيئية على الأحياء المائية أن الأنشطة البشرية هي المصدر الرئي البئيسي للمعادن الثقيلة في خليج أبو قير. 